\author{
Neža Marija Slosar \\ Jelšane \\ DOI: 10.4312/SSJLK.57.101-105
}

\title{
Ustvarjalke v slovenskem jeziku, literaturi in kulturi skozi ulična poimenovanja
}

Prispevek se na podlagi dosedanjih teoretskih obdelav ulične toponomastike (Urška Perenič, Anže Slana, Michael Billig, Maoz Azaryahu) osredišči na poimenovanja ljubljanskih ulic po ženskah. S pomočjo prilagojene tipologije poimenovanj ulic so razvrščene vse ljubljanske ulice, poimenovane po ženskah, čemur sledi še časovna umestitev poimenovanj. Predstavljene so tudi prostorske umestitve t. i. ženskih ulic. V zaključku skušamo podati nekaj preliminarnih opažanj, kako se skozi poimenovanja ulic po književnicah odraža duh časa in družbe.

toponomastika, ulice, Ljubljana, slovenske književnice

On the basis of previous theoretical discussions of the toponomics of street names (Urška Perenič, Anže Slana, Michael Billig, Maoz Azaryahu), the paper considers Ljubljana streets named after women. With the help of an adapted typology, all the Ljubljana streets named after women are characterised, following the chronology of their naming. The spatial location of these "women's streets" are also considered. By way of conclusion, some preliminary observations are offered regarding how the spirit of the times and of society is expressed through naming streets after women writers.

toponomics, streets, Ljubljana, Slovene female writers

\section{Teoretska izhodišča}

Na področju kulturne geografije ulična poimenovanja med drugimi obravnava Maoz Azaryahu, ${ }^{1}$ "ki dejanje poimenovanja ulic razume predvsem kot politično dejanje in toponomastiko umešča v kontekst političnih simbolov « (Slana 2017: 12). Ulice ohranjajo spomin na preteklost, na dogodke in osebe, ki si jih je vredno zapomniti (Azaryahu 1996: 312). Še več: "ulice s komemorativnimi poimenovanji kažejo in prezentirajo določeno različico zgodovine, ki je $v$ družbi uradno priznana. $S$ tem odsevajo in konkretizirajo ideološka prepričanja vladajočega družbenega sloja ter strukture moči in oblasti« (Slana 2017: 12).

$\mathrm{Na}$ Slovenskem je povezavo med literarno kulturo in prostorom, kamor sodi tudi problematika poimenovanja ulic, ki ju je pri projektu teoretsko in aplikativno pokrivala Urška Perenič, doslej najpodrobneje preučil projekt Prostor slovenske literarne kulture, ki se je v nekaterih segmentih nadaljeval s projektom Nacionalni pesniki in kulturni svetniki Evrope (Perenič 2016: 327). Projekta temeljita na ideji kulturnega svetništva, ki pa ga pri nas obravnava Marijan Dović ter povezuje s konceptom kanonizacije. ${ }^{2}$

Dović (2016: 24) navaja, kaj vse sploh določa možnosti za »biti izbran« in izpelje povezavo svetništva z geografijo ("spominskimi krajik): "Grobovi z nagrobniki, javni spomeniki v parkih in mestnih središčih [...] postopoma oblikujejo gosto geografsko mrežo simbolno investiranih spominskih krajev, v marsičem podobno mreži krščanskih svetniških središč, ki so v srednjem veku prepredla

1 Za več o kulturnem spominu in ulični toponomastiki prim. Perenič 2016: 325-327.

2 Podrobneje v Dović 2012: 71. 
Evropo« (prav tam: 30-31). Čeprav je morda kulturno svetništvo veliko bolj očitno na spominskih ploščah, grobovih, nagrobnikih itn., tudi ulice pomembno zastopajo bolj funkcionalen, vseprisoten kulturni spomin, pri čemer pogosto o osebnostih, po katerih nosijo ulice ime, ne vemo ničesar, čeprav so njihova imena lahko močno usidrana v naš spomin, ker se z njimi pogosto (lahko celo dnevno) srečujemo. "S tega vidika [pa] je praktična funkcija poimenovanja ulic tudi nadrejena simbolni funkciji imena« (Slana 2017: 12).

\section{0 ljubljanskih ulicah}

Ker popisujem zgolj ulice, ki so poimenovane po ženskah, ${ }^{3}$ sem za ta namen prilagodila tipologijo 4 poimenovanj političnih zemljepisnih simbolov, ki poimenovanja deli takole:

- osebnost (ženska poimenovanja) ${ }^{5}$

- intelektualke

- ustvarjalke (8 ulic)

- naravoslovje (0 ulic)

- družboslovke in humanistke (3 ulice)

- povezane z vojno (35 ulic)

- vladarke (2 ulici)

- skupna imena in drugo (7)

V Ljubljani je bilo leta 1876 »izvedeno splošno ulično imenovanje in oštevilčenje hiš po ulicah" (Bernik 1980: 10). Trenutno je $1623^{6}$ uveljavljenih imen za ulice. Od teh je ${ }^{7}$ po ženskah poimenovanih 48 ulic $v 17$ četrtnih skupnostih. Po moških je poimenovanih večina ostalih ulic, pri čemer je tudi veliko takih, ki se ne navezujejo na osebe.

\subsection{Ulice, poimenovane po ženskah skozi čas}

Pri razvrščanju ulic $v$ tipologijo se je pokazalo, da ulice $v$ veliki večini niso poimenovane po obče poznanih osebnostih. Največ ulic (39) je poimenovanih po osebah, ki so povezane z vojno ali spadajo v kategorijo ostalo, iz česar izhaja, da načeloma niso del učnih načrtov v šolah in ne gre za (po)znane osebe. Preostalih 9 ulic je danes poimenovanih po bolj splošno poznanih osebah - intelektualkah (ustvarjalke, naravoslovke, družboslovke, humanistke in vladarke).

Zaradi opazne razlike $v$ razmerju med poimenovanjem ulic po ženskah, povezanih z vojno, in intelektualkami sem na podlagi Bernikove knjige Ljubljanske ulice iz leta $1980^{8}$ razvrstila ulice $v$ časovna obdobja (Tabela 1), ko so bile poimenovane. Ugotovimo, da je večina poimenovanj izhajala iz

3 Pri štetju sem upoštevala samo ulice, ki so neposredno poimenovane po ženskah - tako v kvoti nisem upoštevala npr. Vurnikove ulice, poimenovane po zakoncih Vurnik. Vurnikova sta bila arhitekta, ulica pa je poimenovana po obeh.

4 Predlog se deloma ujema z zakonom (ZDOIONUS), »ki predvideva poimenovanja po zemljepisnih imenih, dogodkih ali datumih in osebnostih « (Slana 2017: 14).

5 Štete so tudi ulice, ki so jih preimenovali in jih danes najdemo pod drugimi imeni.

6 Podatek je bil pridobljen na spletni strani Mestne občine Ljubljana (https://gis03.ljubljana.si/LjubljanskeUlice/).

7 Večina podatkov je iz leta 2017. Pri raziskovanju sta mi bila v veliko pomoč tudi projekta Ljubljanske ulice z ženskimi imeni ter Ljubljanske ulice in ceste, imenovane po ženskah.

8 Bernik (1980: 16) navaja, da je bilo »leta 1952 preimenovanih okrog 50 ulic«, leta »1968 [je bila] uvedena posebna komisija, da obravnava predloge občinskih skupščin in uveljavi enotne kriterije pri uličnem imenovanju«, leta 1975 pa je bil sprejet novi odlok, ki »vsebuje predpise za celotni postopek pri imenovanju ulic« (prav tam: 17). 
obdobja med letoma 1952 in 1991, ko je šlo pri poimenovanjih predvsem za lokalne pobude, ki bi v kolektivnem spominu pomagale ohraniti lokalne borke iz 2. svetovne vojne. V obdobju od 1991 pa so se tudi pod vplivom novega družbeno-političnega sistema začela uveljavljati imena intelektualk.

Tabela 1: Obdobje poimenovanja ulice in prevladujoče področje

\begin{tabular}{|l|l|l|}
\hline Obdobje poimenovanja & Število ulic & Prevladujoče področje \\
\hline $1876-1952$ & $5^{9}$ & splošno, vladarice \\
\hline $1952-1968$ & 8 & vojna \\
\hline $1968-1975$ & 14 & vojna \\
\hline $1975-1991$ & 17 & vojna \\
\hline $1991-$ & 4 & $\begin{array}{l}\text { intelektualke } \\
\text { (ustvarjalke, naravoslovke, družboslovke, humanistke) }\end{array}$ \\
\hline
\end{tabular}

\subsection{Prostorska umestitev ulic}

Omejili se bomo samo na ulice, poimenovane po ženskah, ki so ustvarjale v slovenskem jeziku, literaturi in kulturi. Opisali bomo njihov položaj oziroma umestitev v prostoru glavnega mesta. ${ }^{10}$

\subsection{1}

Luize Pesjakove ulica se nahaja med Topniško ulico in Savsko cesto, poimenovana je bila leta 1958. Preči jo Fabianijeva ulica, poimenovana (1958) po slovenskem arhitektu Maksu Fabianiju (1865-1962), ki sodi tudi na širše umetnostno polje. Čeprav se umetnika nista poznala, saj sta živela in delovala v različnih krajih, ju lahko oba dojemamo kot svojevrstna pionirja - Luizo Pesjak (1828-1898) kot pomembno slovensko intelektualko in eno prvih ustvarjalk v slovenskem jeziku, Maksa Fabianija pa kot enega od utemeljiteljev slovenske moderne arhitekture.

\subsection{2}

Ulica Josipine Turnograjske je v središču mesta, kar ji vsaj na simbolni ravni daje večjo pomembnost, kot če bi se nahajala na obrobju. Prav tako ni nezanemarljivo dejstvo, da je bila ulica poimenovana (že) leta 1937, s čimer je Josipina Turnograjska (1833-1854) prva ustvarjalka, po kateri je bila poimenovana katerakoli ulica v Ljubljani. Ulica na jugu meji na Erjavčevo cesto, ki nosi ime po vajevcu Franu Erjavcu (1834-1887). Josipina Turnograjska in Fran Erjavec sta bila sodobnika. Je pa ulica Josipine Turnograjske pol krajša (pribl. 200 m) kot Erjavčeva cesta (pribl. 550 m).

\subsection{3}

Ulica Mire Miheličeve, poimenovana leta 1987, leži v neposredni bližini OŠ Karla DestovnikaKajuha (1922-1944), ki je začela delovati leta 1976. Karl Destovnik-Kajuh je bil pesnik, Mira

9 Marije Terezije cesta (1876-1919), Gosposvetska cesta (1919-1942), Cesta Arielle Rea (1942-1948), ponovno Gosposvetska cesta (1948-) je šteta samo enkrat.

10 Pri nastajanju članka sem si pri vizualni ponazoritvi pomagala z Google zemljevidi. 
Mihelič (1912-1985) pa pisateljica in prevajalka, oba sta bila tudi borca v 2. svetovni vojni. Poimenovanji v simbolnem oziru utrjujeta njuna pomen na političnem in kulturniškem področju.

\subsection{4}

Ulica Lili Novy, poimenovana leta 1984, se nahaja na Dolgem mostu in poteka vzporedno z Ulico borca Petra in Erbežnikovo ulico. Iz biografij se lahko poučimo, da so bili vsi trije aktivisti OF, sicer pa je bila Lili Novy (1885-1958) pesnica in prevajalka poezije. Manica Koman (18801961) ima svojo ulico (poimenovana leta 1968) v »domačih« Vižmarjah, od koder je prihajala.

\subsection{5}

Vidnejšo umestitev ima v prostoru glavnega mesta Zofke Kvedrove ulica, poimenovana leta 1957 , saj se ulica na jugu stika s Kettejevo ulico (poimenovana 1928). Poznano je, da sta se Zofka Kveder (1878-1926) in Dragotin Kette (1876-1899) poznala ter prijateljevala. Vzporedno z njeno ulico (dve ulici stran proti vzhodu) je Smrekarjeva ulica, poimenovana leta 1957 po Hinku Smrekarju (1883-1942), ki je upodobil tudi Zofko Kveder. ${ }^{11}$ Vsi našteti ustvarjalci predstavljajo umetnostno področje, tako to območje tudi simbolno odslikava odnose med vsemi tremi umetniki.

\section{Nekaj preliminarnih ugotovitev}

Segment uličnih poimenovanj, ki nosijo imena po ženskah, je v primerjavi s poimenovanji po moških sorazmerno majhen, vendar hkrati kar močno odraža položaj in vlogo žensk skozi čas. Po ženskah se imenujejo zgolj $3 \%$ vseh ulic v Ljubljani. Po intelektualkah (mednje štejem ustvarjalke, naravoslovke, družboslovke, humanistke) nosi ime 11 ulic, kar je $23 \%$ ulic, ki so poimenovane po ženskah. Od omenjenih $23 \%$ jih je po književnicah poimenovanih šest, kar je skoraj polovica poimenovanj po intelektualkah in niti pol odstotka (tj. 0,4 \%) vseh ulic. Poimenovanja si časovno sledijo v treh fazah, tako da se najprej pojavijo vladarke, nato borke iz 2 . svetovne vojne, nazadnje intelektualke. »Najuglednejši« položaj v Ljubljani ima Zofka Kveder.

Ženske za razliko od moških osebnosti niso enakovredno prepoznane, ko gre za ohranjanje kolektivnega spomina v prostoru glavnega mesta. Pri poimenovanjih je vsekakor pomembna iniciativa oziroma angažma posameznih predlagateljev. Če bi sklepali po komemorativnih poimenovanjih, imajo ustvarjalke v slovenskem jeziku, literaturi in kulturi obroben položaj.

\section{Viri in literatura}

AZARYAHU, Maoz, 1996: The Power of Commemorative Street Names. Environment and Planning D; Society and Space XIV/3. 311-330. http://citeseerx. ist.psu.edu/viewdoc/download?doi=10.1.1.1019.5916\&rep=rep 1 \&type=pdf BERNIK, Stane idr., 1980: Ljubljanske ulice. Ljubljana: Geodetska uprava Skupščine mesta Ljubljane.

BILLIG, Michael, 1995: Banal Nationalism. London: Sage Publications.

ČIŽMAN, Marko, 2006: Ljubljana: Ulice, ceste in trgi po župnijah. Ljubljana: Nadškofija Ljubljana. http://nadskofija-ljubljana.si/wp-content/uploads/ulice-zupnije.pdf

DOVIĆ, Marijan, 2012: Model kanonizacije evropskih kulturnih svetnikov. Primerjalna književnost XXXV/3. 71-85. https:// www.dlib.si/stream/URN:NBN:SI:DOC-HL1XWZB3/838efdfe-6ede-4cd2-90e1-34c9b618a2dd/PDF

$11 \mathrm{~V}$ istem delu mesta odkrijemo še eno zanimivo povezavo med vzporednima ulicama, in sicer med karantanskima knezoma Hotimirjem in Gorazdom. 
DOVIĆ, Marijan, 2016: Kanonizacija kulturnih svetnikov: analitični model. Marijan Dović (ur.): Kulturni svetniki in kanonizacija. Ljubljana: Založba ZRC, ZRC SAZU. 23-44. http://csaints.zrc-sazu.si/wp-content/uploads/2017/09/01_ Dovi\%C4\%87.pdf

Geni: Ljubljanske ulice z ženskimi imeni. https://www.geni.com/projects/Ljubljanske-ulice-z-\%25C5\%25BEenskimi-imeni/ 621547 (dostop: 29. 3. 2020)

Gis: Ulice v Mestni občini Ljubljana. https://gis03.ljubljana.si/LjubljanskeUlice/ (dostop 29. 3. 2020)

Issuu: Ljubljanske ulice in ceste, imenovane po ženskah. https://issuu.com/knjiznicaljubljana/docs/ljubljanske_ulice_ po_zenskah_koncna (dostop 29.3. 2020)

PERENIČ, Urška, 2014: Writers on the Streets of Ljubljana: the Onomastica of Street Names. Slovene Studies XXXVI/2. 111 -129. https://journals.lib.washington.edu/index.php/ssj/article/view/15356/12796

PERENIČ, Urška, 2016: Toponomastika uličnih imen, nacionalna identiteta in pripadanje: literarne ulice v ožjem središču Ljubljane. Marijan Dović (ur.): Kulturni svetniki in kanonizacija. Ljubljana: Založba ZRC, ZRC SAZU. 325-348. http:// csaints.zrc-sazu.si/wp-content/uploads/2017/09/20_Pereni\%C4\%8D.pdf

Sistory zgodovina Slovenije. https://www.sistory.si/ (dostop: 29. 3. 2020)

SLANA, Anže, 2014: Sledi slovenskih literatov v Kamniku: Ulična poimenovanja. Diplomsko delo. Ljubljana: Filozofska fakulteta.

SLANA, Anže, 2017: Spominska obeležja slovenskih književnikov: Ulice, ustanove in spomeniki v Kamniku. Magistrsko delo. Ljubljana: Filozofska fakulteta. 